\title{
TANGGUNG JAWAB PEMERINTAH TERHADAP PENANGGULANGAN COVID- 19 DALAM RANGKA PELAYANAN MEDIS DI RUMAH SAKIT
}

\author{
Ni Komang Rosi Triana Ayu Nuratih, I Ketut Kasta Arya Wijaya, Ida Ayu Putu Widiati \\ arisrosi19@gmail.com, kastaaryawijaya@gmail.com, idaayuputuwidiati@gmail.com \\ Fakultas Hukum, Universitas Warmadewa, Denpasar-Bali, Indonesia
}

\begin{abstract}
Abstrak
Kesehatan merupakan aspek penting dan sekaligus menjadi tolak ukur kesejahteraan masyarakat dari suatu negara. Pengembangan pembangunan nasional yang salah satunya di bidang kesehatan harus sesuai dan berlandaskan pada Pancasila dan Undang- Undang Negara Republik Indonesia Tahun 1945. Tujuan penelitian ini adalah untuk mengungkap tanggung jawab pemerintah terhadap penanggulangan pasien covid-19 dan perlindungan hukum bagi pasien covid-19 dalam rangka pelayanan medis di rumah sakit. Metode penelitian dalam penulisan ini adalah penelitian hukum normatif. Pengkajiannya dilakukan dengan studi kepustakaan yang secara khusus memiliki keterkaitan dengan ilmu hukum dibidang kesehatan. Sumber data yang digunakan yaitu sumber bahan hukum primer, sekunder dan tersier dan dianalisis secara sistematis. Hasil penelitian ini menunjukan bahwa pertanggungjawaban dari pemerintah bagi pasien covid-19 memberikan hak-hak kepada pasien yang diatur dalam peraruran terkait. Jika pemerintah dan pihak terkait melanggar hak-hak yang seharusnya diterima oleh pasien covid-19 maka dapat dikenakan sanksi sesuai dengan peraturan yang berlaku. Perlindungan hukum atau diterbitkannya aturan hukum mengenai hak-hak dari pasien covid-19 bertujuan untuk melindungi masyarakat itu sendiri.
\end{abstract}

Kata Kunci: Pasien Covid-19, Perlindungan Hukum, Tanggung Jawab Pemerintah.

\begin{abstract}
Health is an important aspect and become a measure of the welfare of the people of a country. The development of national development, one of them is in the health sector, must be in accordance with and based on Pancasila and the 1945 Constitution of the Republic of Indonesia. The purpose of this research is to reveal the government's responsibility for handling Covid-19 patients and legal protection for Covid-19 patients medical services in the hospital. The research method used is normative. The assessment is carried out by means of a literature study which is specifically related to law in the health sector. The data sources used were prmiary, secondary and tertiary sources and were analyzed systematically. The result of this research indicates that the responsibility of the government for Covid-19 patients provides rights to patients regulated in related regulations. If the government and parties who violate the rights that should be received by Covid-19 patients, they can be subject to sanctions in accordance with applicable regulations. Legal protection or the issuance of legal rules regarding the rights of Covid-19 patients aims to protect the community itself.
\end{abstract}

Keywords: Covid-19 Patients, Legal Protection, Government Responsibility.

\section{PENDAHULUAN}

Setiap kegiatan yang bertujuan untuk meningkatkan mutu kesehatan dan meningkatkan standar kesehatan masyarakat dilaksanakan dengan tindakan non diskriminatif, partisipatif, perlindungan dan berkesinambungan sehingga bisa meningkatan mutu dan standar kesehatan masyarakat agar dapat membantu dan meningkatkan pembangunan nasional di sektor lainnya. Saat ini di dunia ataupun Indonesia sendiri terdapat virus menular yang dapat mengakibatkan ketidakstabilan kesehatan pada masyarakat, sehingga dapat mempengaruhi segala aspek dalam kehidupan berrnasyarakat dan dapat menghambat pelayanan kesehatan di rumah sakit, perrumbuhan ekonomi serta pembangunan nasional secara umum.

Virus yang penyebaranya sangat cepat ini disebut dengan Sars-cov-2 atau yang lebih dikenal dengan virus corona. Awalnya virus ini berkembang di Wuhan China dan mulai menyebar sampai hampir ke selurnh dunia terrnasuk Indonesia. Pada tanggal 11 maret World Health Organization yang 
selanjutnya disebut WHO menyatakan bahwa penyakit covid-19 yang disebabkan oleh virus corona ini dinyatakan sebagai pandemi global dengan jumlah orang yang terjangkit mencapai 121.000 orang.

Persoalan kesehatan di Indonesia bukan merupakan persoalan yang baru tapi juga persoalan yang banyak pembaharuannya. Oisebut banyak pembaharuan dikarenakan istilah dari upaya kesehatan itu sendiri merupakan ha! atau istilah yang dapat dikatakan baru. Upaya kesehatan bersanding dengan pelayanan kesehatan yang memisahkan 2 jenis upaya yang berbeda. Pelayanan kesehatan lebih mengarah kepada pelayanan kesehatan yang dilakukan oleh mereka yang sudah professional dan lebih bersikap pasif, serta mengandalkan atau mempercayakan kesehatan mereka kepada mereka yang sudah professional. Sedangkan penyelenggara kesehatan lebih mengandalkan tindakan aktif dari masyarakat dan komunitas tanpa adanya kaum profesional dalam pelaksanaanya (Nabila \& Nayla, 2014).

Semua elemen masyarakat memiliki peranan penting dalam penyelenggaran kesehatan di lingkungan mereka dan jika terdapat kasus kesehatan yang spesialistik maka masyarakat memburuhkan kaum profesional dan kaum profesional wajib membanru menyelesaikan atau menangani permasalahan kesehatan tersebut. Dalam fungsinya kaum professional diharapkan lebih aktif bertindak sebagai fasilitator dalam menyelenggarakan dan memelihara kesehatan dalam masyarakat (Tjiong, 1991). Dokter, perawat atau mereka yang dinyatakan memiliki kompetensi dalam melakukan pelayanan kesehatan merupakan salah satu tenaga ahli profesional, dapat dinyatakan sebagai kaum profesional dalam kesehatan dalam melakukan pelayanan medis dikarenaka dokter memiliki peranan yang penting. Upaya maksimal yang dilakukan oleh dokterdalam menangani pasien bertujuan agar masyarakat mendapat hak atas kesembuhan dan pemulihan kesehatannya.

Hubungan dokter dan pasien jika dikaitkan kedalam hukum, maka dapat dikatakan hubungannya sebatas hubungan hukum keperdataan. Dikelompokkan kedalam hubungan hukum perdata karena pasien yang datang ke dokter berharap untuk disembuhkan penyakitnya dan dokter akan berupaya menyembuhkan penyakit pasiennya. Hubungan keperdataan adalah hubungan hukum bagi mereka yang dinyatakan posisinya sederajat dan memiliki potensi akan masuk ke ranah hukum lainnya apabila terjadi tindakan yang merugikan salah satu pihak.

Selain hubungan terapeutik antara pasien dengan dokter, rumah sakit sebagai sarana pengobatan juga merniliki keharusan dalam memberikan pelayanan dan perlindungan terhadap pasien. Rumah sakitjuga memiliki wewenang memilih dokter dan perawat yang akan dipekerjakan dengan melihat catatan kompetensi dan pengalaman yang telah diperoleh sebelumnya, itu bertujuan agar rumah sakit dapat menjamin pasiennya mendapat pelayanan kesehatan yang sebagaimana mestinya. Pasien yang menggunakan jasa dokter sejatinya dipandang sebagai konsumen, hat tersebut dibenarkan oleh UU No. 8 Tahun 1999 Tentang Perlindungan konsumen yang menjelaskan bahwa konsumen adalah mereka yang menggunakan barang atau jasa yang tersedia dalam masyarakat atau diperdagangkan baik itu untuk kepentingan sendiri keluarga dan lain sebagainya. UU No 29 Tahun 2004 Tentang Praktik Dokter dan UU No. 362009.

Tentang Kesehatan menyatakan bahwa pasien harus dipandang sebagai subjek yang memiliki pengaruh serta dampak bagi hasil akhir dari pelayanan kesehatan apakah dapat dikatakan memuaskan atau tidak, atas dasar itulah pasien dipandang sebagai subyek dan tidak sebagai objek semata (Suharjo, 2008). Hak-hak pasien harus dipenuhi mengingat kepuasan pasien terhadap pelayanan kesehatan menjadi tolak ukur dalam mutu terhadap pondasi dan pelayanan serta perlindungan kesehatan bagi masyarakat. Sedangkan ketidakpuasan pasien terhadap pelayanan kesehatan dapat menimbulkan pangkal tuntutan hukum yang bisa diajukan pasien baik itu kepada tenaga medis dan rumah sakit.

Dengan mewabahnya virus corona di lndonesia, maka pemerintah wajib memberikan edukasi dan pemahaman ke masyarakat tentang apa itu virus corona, apa dampak yang ditimbulkan dari virus ini dan bagaimana penularannya dapat terjadi. Mengingat covid-19 ini sudah dinyatakan oleh presiden sebagai bencana nasional maka pemerintah memiliki tanggung jawab atas pelayanan kesehatan yang memadai bagi masyarakat dan pemerintah juga memiliki kewajiban memberikan perlindungan bagi tenaga medis yang menjadi garda terdepan dalam penanganan virus ini.

(Firmansyah et al., 2020) perlu adanya tindakan dari pemerintah dengan memperhatikan perencanaan manajemen, perencanaan ini diharapkan dapat mengurangi penyakit penularan dan angka kematian. Salah satu langkah mitigasi yang dilakukan oleh pemerintah menyediakan medis pelayanan kepada tenaga kesehatan dalam penanganannya pasien yang dikonfirmasi positif Covid-19. Salah satu 
upaya pemerintah harus ditekankan pada pelayanan publik dengan memperhatikan kegiatan-kegiatan yang dapat memutus rantai penyebaran virus corona baik yang berskala daerah maupun berskala nasional (Syafrida \& Hartati, 2020). Lebih lanjut berkaitan dengan kebijakan pemerintah di sektor kesehatan dan ketertiban masyarakat dan hak atas kesehatan dapat ditemukan di instrumen nasional pada pasal 28H ayat (1) dan pasal 34 ayat (3) amandemen UUD 1945, pasal 9 UU No. 39 tahun 1999 (Kancana et al., 2020).

Maka berdasarkan penjelasan diatas, penelitian ini berujuan untuk menganalisis tanggung jawab pemerintah terhadap penanggulangan pasien covid-19 perlindungan hukum bagi pasien covid19 dalam rangka pelayanan med is di rumah sakit.

\section{METODE PENELITIAN}

Penelitian ini menggunakan metode penelitian hukum normatif, yang dimana pengkajiannya dilakukan melalui studi kepustakaan di bidang hukum kesehatan. Pendekatan masalah yang digunakan dalam penelitian ini adalah pendekatan perundang-undangan dan pendekatan konseptual yang menekankan pada pandangan dan doktrin-doktrin yang berkembang dalam ilmu hukum khususnya di ilmu hukum kesehatan. Sumber bahan hukum yang digunakan adalah bahan hukum primer yang didapat dengan menganalisis peraturan perundang-undangan, risalah resmi, dan beberapa keputusan-keputusan yang menyangkut dengan judul penelitian ini. Bahan hukum sekunder didapat dari menganalisis buku-buku,jurnal-jumal dan hasil-hasil penelitian terdahulu yang memiliki keterkaitan dengan judul penulisan ini. Dan bahan hukum tersier yang dapat menunjang bahan hukum primer dan sekunder seperti kamus-kamus hukum dan tulisan yang dapat diakses melalui internet. Bahan-bahan hukum yang telah diperoleh kemudian dianalisis secara sistematis menggunakan argumentasi hukum berdasar pada logika-logika hukum. Sehingga menjadikan substansi dalam tulisan ini sesuai atau selaras dengan aturan- aruran atau sumber hukum dan doktrin-doktrin yang dijadikan sebagai acuan dalam tulisan ini.

\section{HASIL DAN PEMBAHASAN}

\section{Tanggung Jawab Pemerintah Dalam Penanggulangan Pasien Covid-19}

Pertanggungjawaban pemerintah dalam kaitannya dengan hokum administrasi yaitu tanggung jawab pemerintah dengan warga negaranya yang berdasarkan atas segala ketentuan hukum yang berlaku. Dalam persfektif hukum publik kebijakan pemerintah digunakan dan dituangkan kedalam beberapa instrumen hukum yang disebut dengan kebijakan. Hubungan hukum ini dikatakan bersifat intern yang artinya adanya hubungan hukum antar negara dan warga negaranya (HR, 2006).

Tugas dan fungsi dari pemerintah menjaga berlangsungnya kehidupan bermasyarakat antar masyarakat baik itu dalam lingkup kecil atau dalam lingkup masyarakat yang lebih besar. Dan pemerintah juga merupakan subjek yang rnemproduksi, mendistribusikan atau menjual segala pemenuhan masyarakat baik dalam bentuk barang atau jasa melalui jasa publik atau layanan civil. Dalam penanggulangan Covid-19 di Bali melibatkan desa pakraman atau desa adat dimana desa adat rnempunyai kewenangan salah satunya turut serta menentukan setiap keputusan dalam pembangunan termasuk penanggulangan Covid-19 yang ada di wilayahnya/palemahan (Parwata \& Wijaya, 2018). Tugas pemerintah adalah melayani masyarakat dan dalam hal ini adalah dengan memberikan atau mendahulukan kepentingan publik, mempermudah segala urusan publik dan memberikan kepuasaan terhadap pelayanan publik. Sedangkan tugas pemerintah dalam rnengatur masyarakat lebih menitikberatkan pada posisi dan jabatan birokrasi. Fungsi dari pemerintah adalah fungsi primer yang dimana pemerintah berfungsi sebagai pelayanan, provider dalam pelayanan baik yang bersifat privat dan yang bersifat publik, pemerintah juga mempunyai fungsi sekunder yaitu sebagai pemberdayaan, penyelenggaraan pembangunan dalam proses pemberdayaan. Fungsi pemerintah dalam hukum publik adalah sebagai pembuat peraruran dan pelaksana peraturan agar memihak bagi masyarakat luas, tanpa adanya salah saru kepentingan yang diutamakan di dalamnya.

Dalam situasi merebaknya wabah dari virus covid-19 menyebabkan pemerintah mengeluarkan kebijakan-kebijakan yang dapat menunjang keburuha terhadap pelayan public dibidang kesehatan bagi masyarakat. Kebijakan yang dikeluarkan pemerintah dengan tujuan mengatasi covid19 adalah Keputusan Presiden Nomor 9 Tahun 2020 Tentang Perubahan atas Keputusan Presiden Nomor 7 Tahun 2020 mengenai Gugus Tugas Percepatan Penanganan Coronavirus dan Keputusan 
Presiden Nomor 11 Tahun 2020 Tentang Penetapan Kedaruratan Kesehatan Masyarakat di masa Covid-19.

Pemerintah memiliki kewajiban dalam upaya pemenuhan hak pelayanan kesehatan bagi masyarakat. Pemenuhan hak atas pelayanan kesehatan bagi masyarakat tersebut dapat digolongkan menjadi 3 yaitu, to respect atau menghorrnati, to protect atau melindungi dan to fulfill atau memenuhi. To Respect atau menghormati dalam konteks ini adalah tindakan apa yang tidak akan dilakukan atau apa yang akan dihindari, Negara harus menahan diri dalam melaksanakan tindakan-tindakan yang berpotensi akan merugikan warga binaan antara lain menghindari kebijakan terhadap limitasi atas pelayanan kesehatan dan tidak merahasiakan segala informasi kesehatan yang penting. Mempertimbangkan dampak hak atas kesehatan bagi masyarakat sebelum menyerujui komitmen internasional.

To Protect atau melindungi merupakan upaya tindakan untuk mencegah pelaku dari negara luar untuk melakukan diskriminasi yang mengakibatkan terhambatnya akses kesehatan di dalam negeri. Pemerintah memberikan kebijakan berupa peraturan untuk melindungi dan menikrnati fasilitas kesehatan yang adil dan memberikan keuntungan bagi warga negaranya.

To Fulfill atau memenuhi merupakan kewajiban pemerintah terhadap pemenuhan secara progresif di bidang kesehatan dan alokasi dari sumber daya serta obligasi dengan rujuan untuk pemenuhan hak-hak masyarakat dalam bidang kesehatan dan negara juga memfasilitasi fasilitas kesehatan bagi masyarakat. lmplementasi dari ketiga kebijakan pemerintah di atas dapat dilaksanakan dengan dikeluarkan kebijakan-kebijakan berupa peraturan di bidang kesehatan serta anggaran untuk memfasilitasi sarana kesehatan itu sendiri.

Dimasa pandemic seperti ini, pembiayaan atas pelayanan kesehatan bagi masyarakat yang terpapar virus covid-19 akan dibebankan ke pemerintah baik itu melalui pemerintah pusat, pemerintah daerah dan sumber dana yang terkait lainnya sesuai dengan yang tertuang dalam Keputusan Menteri Kesehatan Republik Indonesia omor HK.01.07/Menkes/104/2020. Pembebasan atas biaya pengobatan pasien dimulai sejak pasien tersebut ditetapkan sebagai suspek yang telah terpapar virus dengan bukti surat laporan kesehatan dari laboratorium. Atau bisa juga saat pasien telah dinyatakan positif terpapar virus dari laboratorium hingga dinyatakan sembuh atau meninggal dunia. Yang termasuk ke dalam pembebasan biaya adalah, biaya administrasi atas pelayanan, keperawatan IGO, ruang isolasi, ruang ICU, jasa dokter, laboratorium dan radiologi, obat-obatan dan alat kesehatan lainnya.

\section{Perlindungan Hukum Bagi Pasien Covid-19 Dalam Rangka Pelayanan Medis Dirumah Sakit}

Perlindungan hukum dalam praktiknya dapat dibedakan menjadi dua yaitu perlindungan hukum preemtif, perlindungan hukum preventif dan perlindungan hukum represif. Perlindungan hukum preemtif adalah perlindungan hukum dengan upaya awal yang dilakukan oleh pihak kepolisian dengan tujuan untuk mencegah terjadinya suatu kejahatan. Upaya ini dapat dilakukan dengan cara menanamkan norrna-norma yang benar dan norma tersebut akan dijadikan landasan dalam kehidupan bermasyarakat. Dengan cara itulah pihak kepolisian dapat meminimalisir terjadinya suatu tindak kejahatan (Zaidan, 2016).

Perlindungan hukum preventif adalah perlindungan hukum yang dilakukan dengan upaya melakukan tindakan yang dapat menghilangkan kesempatan seseorang dalarn melakukan tindak kejahatan. Karena upaya mencegah kejahatan lebih baik daripada mendidik pelaku kejahatan menjadi orang yang lebih baik. Penerapan perlindungan secara preventif dapat dilakukan dengan dua metode, yaitu moralistik dan abolitionist. Moralistik dilakukan dengan cara melakukan pendidikan moral dan abolisionistik dilakukan dengan cara penanggulangan konsepsional dan harus dilakukan berdasarkan penelitian di bidang kriminologi.

Perlindungan hukum secara represif dilakukan dengan cara menegakkan hukum bagi mereka yang melakukan tindak kejahatan. Penegakan hukum yang dimaksud disini adalah penjatuhan hukum bagi mereka yang melakukan tindak kejahatan, dengan harapan mereka dapat menyaclari tindakan yang telah dilakukan bertentangan dengan ketentuan hukum yang berlaku. Upaya ini juga dapat dilakukan oleh pihak kepolisian dengan cara melakukan tindakan fisik dan menggunakan senjata api. Dalam masa pandemic seperti ini perlunya pasien mendapatkan perlindungan hukum sesuai dengan peraruran perundang-undangan yang berlaku, dengan tujuan untuk memberikan rasa aman bagi pasien serta melindungi hak-hak pasien dalam menerima pelayanan kesehatan. Perlindungan bagi pasien 
adalah pertanggungjawaban hukum atas tindak tindak atau upaya melawan hukum yang dilakukan oleh tenaga medis ataupun rumah sakit (Hariyani, 2010).

Dokter dapat digugat apabila dokrer tersebut melakukan tindakan yang dianggap menimbulkan kerugian bagi pasien karena tidak melakukan tindakan sebagaimana prosedur dari suatu tindakan medis. Yang harus dibuktikan bahwa memang tergugat lalai dalam menjalankan tugas. Dan perbuatan tersebut menimbulkan dampak atau kerugian yang nyata bagi pasien. Perlindungan pasien menurut yang tertuang dalam Undang-Undang Perlindungan konsumen, adalah tindakan yang merugikan bagi pasien yang melibatkan tenaga medis dalam melakukan pelayanan kesehatan dan dapat dikenakan ganti rugi. Ganti rugi tersebut dapat berupa pengembalian uang dan berupa pelayananjasa dibidang kesehatan yang setara denganjumlah kerugian yang dialami pasien. Perlindungan pasien menurut yang tertuang dalam Undang-Undang Praktik Kedokteran, apabila terjadi kerugian yang dialami oleh pasien yang ditimbulkan dari pelayanan kesehatan, maka pasien tersebut dapat mengajukan pengaduan ke Majelis Kehormatan Disiplin Kedokteran Indonesia. Pemenuhan hak-hak bagi pasien yang terpapar covid-19 dapat direalisasikan dengan cara, menyediakan alat Pelindung Diri atau APO sesuai dengan ketentuan PP No. 40 Tahun 1991 Tentang Penanggulangan Wabah Penyakit Menular, sehingga pemerintah diwajibkan rnenyediakan APO guna merealisasikan pelayanan kesehatan dengan tujuan menanggulangi covid-19. Pemerintah menjamin atas pelayanan kesehatan bagi masyarakat. Perlindungan hukum bagi pasien tersebut tertuang dalam bentuk perlindungan hukum baik itu secara keperdataan, pidana atau administrasi. Pasien yang dirugikan dapat meminta ganti rugi, melakukan tuntutan sesuai dengan kerugian yang pasien alami, baik itu berupa tunrutan keperdataan maupun pidana.

\section{SIMPULAN DAN SARAN}

\section{Simpulan}

Dapat disimpulkan bahwa, pemerintah memiliki tanggungjawab atas pasien yang terpapar virus covid-19 berupa pemenuhan hak-hak pasien atau masyarakat dengan cara menyediakan alat pelindung diri, perawatan medis dan menjamin biaya pelayanan kesehatan selama pasien tersebut dirawat, dengan tujuan untuk memberikan kesejahteraan dan rasa aman bagi masyarakat dibidang kesehatan dan perlindungan hukum yang diberikan kepada pasien covid-19 yang menjalani pelayanan medis dirumah sakit, berupa diterbitkannya kebijakan-kebijakan dan aturan-aruran yang diterbitkan oleh pemerintah dengan tujuan untuk rnelindungi hak-hak dari masyarakat khususnya pasien covid-19. Kewajiban pemerintah atas pemberian pertanggungjawaban terhadap pelayanan kesehatan berakibat pada terlibat aktifnya pemerintah dalam kehidupan warga negaranya.

\section{Saran}

Kepada pemerintah disarankan agar, pengeluaran atau penerbitan kebijakan-kebijakan yang menyangkut pasien covid-19 agar dilaksanakan dengan baik, tertib, serta memberikan keuntungan bagi segala pihak yang terlibat baik itu pasien, tenaga medis dan rumah sakit. Kepada rumah sakit diharapkan agar, memberikan pelayanan yang baik bagi masyarakat yang terpapar virus covid-19 sesuai dengan standar operasional prosedur pelayanan medis. Kepada masyarakat disarankan agar, mematuhi peraturan atau kebijakan- kebijakan yang telah diterbitkan oleh pemerintah, demi mencegah penularan virus ini secara masif dan lebih luas. Sehingga dapat membantu pemerintah, tenaga medis dan rumah sakit dalarn melakukan pelayanan yang optimal serta upaya dalam pencegahannya.

\section{DAFTAR PUSTAKA}

Firmansyah, M. I., Rahmanto, F., \& Setyawan, D. (2020). The Preparedness for the Covid-19 Pandemic Management in Indonesia. Jurnal Administrasi Kesehatan Indonesia, 8(2), 188-201.

Hariyani, S. (2010). Sengketa Medik Alternatif Penyelesaiaan Perselisihan Antara Dokier dengan Pasien. Diadit Media.

HR, R. (2006). Hukum Administrasi Negara. PT Raja Grafindo Persada. Jakarta.

Kancana, H., Dauri, Rahmatinnur, U., Nisa, N. W., \& J., R. D. (2020). Bentuk Tanggung Jawab Negara Menghadapi Covid-19 dalam Perspektif Otonomi Daerah (Telaah Peraturan Pemerintah Nomor 21 Tahun 2020 tentang Pembatasan Sosial Berskala Besar). Jurnal Pemikiran Dan Penelitian Ilmu-Ilmu Sosial, Hukum, \& Pengajarannya, 15(2), 87-200. 
Nabila, \& Nayla. (2014). Perlindungan Hukum Terhadap Pasien Operasi Caesar dalam Persetujuan Tindakan Medis Di Rumah Sakit Umum Daerah Kajen Kabupaten Pekalongan. Yogyakarta

Parwata, A. . G. O., \& Wijaya, I. K. K. A. (2018). Eksistensi Desa Pakraman dalam Pengelolaan Kepariwisataan Budaya Bali (Kajian Terhadap Peraturan Daerah Provinsi Bali No 2 Tahun 2012, tentang Kepariwisataan Budaya Bali). Jurnal Kertha Wicaksana, 12(1), 69-75.

Suharjo, J. (2008). Membangun Budaya Keselamatan Pasien dalam Praktik Kedokteran. Kanisius. Yogyakarta.

Syafrida, \& Hartati, R. (2020). Bersama Melawan Virus Covid 19 di Indonesia. Jurnal Sosial \& Budaya Syar-i, 7(6), 495-508.

Tjiong, R. (1991). Problem Etis Upaya Kesehatan. Gramedia Pustaka Utama. Jakarta

Zaidan, M. A. (2016). Kebijakan Kriminal. Sinar Grafika. Jakarta 